\title{
EFFECT OF SKILLS, CAPABILITIES, EDUCATION AND TRAINING ON ACCOUNTING INFORMATION SYSTEM USER SATISFACTION
}

\author{
Holiawati \\ Universitas Pamulang \\ dosen00011@unpam.ac.id
}

\begin{abstract}
This study aims to examine the effect of skills, abilities, education and training on the satisfaction of users of accounting information. The research method uses quantitative methods. The sample in this study were UNPAM students who worked as accounting and had received education and accounting information system training and training. The results of this study are the influence of skills on the satisfaction of users of accounting information, there is an influence on the ability of users of accounting information satisfaction and there is no influence of education and training on the satisfaction of users of accounting information.
\end{abstract}

Keywords: Satisfaction of accounting, skills, education and training information system

\section{INTRODUCTION}

Current technological developments in the world are increasingly sophisticated and growing rapidly as evidenced by the emergence of information technology devices as a means of supporting people's lives, both for the interests of organizations, personal, social, and business. The development of these technologies also triggers and influences the development of information systems, especially accounting information systems. Now, both private companies and government companies are using computerized accounting information systems, which are using accounting information systems applications to collect, classify, process, analyze, and communicate information decision-making with financial orientation that is relevant to external parties and the company efficiently and controlled.

This accounting information system application varies in shape in each company, according to the needs of the company. The application serves as a company tool to measure the performance of the accounting information system used by the company which has been running. Furthermore, information from performance measurement can also be used by company managers as material to evaluate the suitability of applications used with the needs in the field, specifically facilitating end users in their operation, being effective in applications, and lack of system errors in applications.

User satisfaction with an information system is how users perceive information systems in real terms, but not on technical quality systems 
(Guimaraes, Staples, and McKeen, 2003). The use of technology in producing information should consider users (Anak agung, 2005). It is not uncommon to find that the technology used to produce information is often inaccurate or not utilized optimally by the user, then the information produced does not provide benefits to the company.

Expertise is often associated with knowlodge and skill. Someone will be said to be an expert if he/she has the knowledge and skill. If the user has the expertise and understanding of the system used, the user will feel more have the system used. User expertise in the use of information systems in a company, can be seen from the ease of the user in identifying data, accessing data and interpreting the data.

The financial statements produced by the accounting information system must be of high quality. The good and quality financial statements are prepared by following the applicable Accounting Standards. Information generated by an information system requires humans to produce quality information. Information system is a system whose purpose is to produce output (information) that is useful, relevant, timely, and accurate (Romney, 2006). Outputs that are not supported by these three pillars cannot be said to be useful information for an organization in delivering its financial statements.

Based on the background above, encouraging researchers to focus on examining how much influence the skills, abilities, education and training on the user satisfaction of the accounting information system .

\section{Formulation of Problem}

This study aims to examine the empirical evidence of the influence of skills, abilities, education and training on user satisfaction of Accounting
Information Systems (AIS). The problem of this research is as follows

1. Does the skill affect the satisfaction of AIS users?

2. Does the ability affect the satisfaction of AIS users?

3. Does Education and Training affect the satisfaction of AIS users?

\section{LITERATURE REVIEW}

2.1. Theories underlying Information Systems Research

One of the theories regarding the use of information technology systems that are very influential and commonly used to explain individual acceptance of the use of information systems is the Theory Acceptance Model (TAM) described by Davis (1989). The TAM model assumes that someone who adopts a technology is generally determined by cognitive processes and aims to satisfy their use or maximize the usefulness of the technology itself. TAM shows usability and ease of use will affect the individual's intention to use information technology which is divided into usage behavior (usage) with two frame variables, namely perceived usefulness.

\subsection{Accounting Information Iystem (AIS)}

Bodnar (2004) argues that AIS is a collection of resources that will transform financial data data into information that is either manually or with computer assistance that is useful for decisions. Accounting Information Systems according to La Midjan and Azhar $(2001 ; 30)$ aim to encourage as optimal as possible so that accounting can produce a variety of quality accounting information, namely information that is timely, relevant, accurate and complete, as a whole the information is meaningful and useful for corporate policy making . 


\subsection{Skill}

According to Laudon (2008), users (users) need to know and understand information technology used by companies in their information systems. If the user has the skills and understanding skills of the system used by the user will feel more have the system used, so they can use the system properly.

Expertise according to Harrison and Rainer (1992) in Anak Agung (2005) is an estimate of a person's ability to carry out work successfully, someone who considers himself capable of carrying out tasks tends to be successful. A person's expertise in operating a computer can be obtained through education both formally and informally.

\subsection{Ability}

The ability of users to operate a new information system is needed. According to Robbins (2005: 45) the ability of users can be seen from how the system user runs an existing accounting information system.

\subsection{Education and Training}

According to Wilkinson (2000: 557) training and education for employees is needed so that employees are more skilled in using the new system, so the training and education program will provide benefits to employees and system users in carrying out the company's operational activities.

\subsection{Satisfaction}

Satisfaction of information usage according to Al Ghatani (2001) is a multidimensional attitude from users towards different aspects of information systems. The satisfaction of end-user information systems is one of the benchmarks for the success of accounting information systems.

\section{Thinking Framework}

This study intends to examine the effect of skills, abilities, education and training on the satisfaction of users of Accounting Information Systems. By using primary data obtained from the results of questionnaires given to students and lecturers of the S1 study program at the University of Pamulang who have run the accounting information system where they work. From the picture below you will see the relationship between the variables of this research.

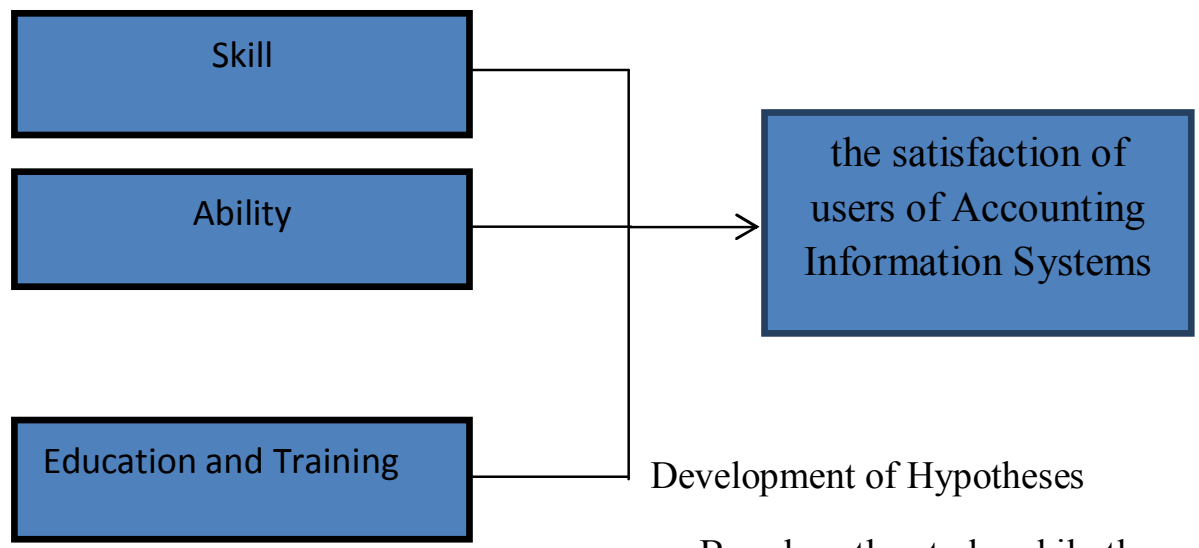

Based on the study while the authors state the hypothesis as follows:

1. Effect of AIS user skills on AIS user satisfaction. 
The researcher assumes that the skills possessed by AIS users will influence the satisfaction of AIS users as practiced by supporters with the research conducted by Mahdiar Rahmi (2008) with significant and significant results, and according to Laudon's theory (2008), users (users) need to know and understand information technology used by companies in information systems, research Rini (2009), the results show that user expertise has a significant positive effect on the application of AIS.

H1: Suspected skills affect satisfaction of AIS users.

2. Effect of the ability of AIS users on satisfaction of AIS users.

this study assumes that the ability of AIS users will have a significant effect on the satisfaction of AIS users, Cecilia and Ellen (2010), Soegiharto (2001), Fung (2002) whose results are significant and significant and prove by research conducted by Choe (1996), Sasmita (2003), Almilia and Brilintien (2007) which state the ability of information system users to have a positive and insignificant effect.

$\mathrm{H} 2$ : It is assumed that the ability of AIS users has a significant effect on the satisfaction of AIS users

3. Effect of Education and Training on the satisfaction of AIS users

The researcher assumes that education and training of AIS users will affect the satisfaction of AIS users such as cicilia and elen (2010) where education and training have a significant effect on user satisfaction, and according to the results of the Soegiharto (2001) study.

H3 : Allegedly education and training have a significant effect on the satisfaction of users of Accounting Information Systems .

\section{RESEARCH METHOD}

\subsection{Type of Research}

This research is classified into causality research, this study conducted an experiment in predicting the influence of one variable with other variables, then a description that revealed the magnitude or smallness of an influence or relationship among variables expressed in numbers.

3.2. Population, Samples and Data Collection Techniques

1. Population

In this study the population is students and lecturers at the University of Pamulang .

2. Sample

The researcher decided that the study sample was withdrawn by purposive sampling, based on certain criteria. The criteria that researchers do are:

a. University of Pamulang students and lecturers who work using accounting information systems

b. Respondents have used the Accounting Information System for at least 6 months in their work.

c. Having done education and training on accounting information systems.

\section{Data Collection Techniques}

The data collection technique used in this study is by interviewing students and lecturers of the University of Pamulang who use AIS in their offices, followed by distributing questionnaires to obtain authentic evidence of respondents' answers to the statements the researchers gave .

\subsection{Types and Data Sources}

The type of data in this study uses the primary data type in the form of interviews and giving questionnaires directly to the users of Accounting Information Systems, namely the students of the Accounting Accounting Study Program at Pamulang University 
who have worked and practicing lecturers at S1 Pamulang.

3.4. Data analysis method

1. Validity Test

2. Reliability Test

3. Test of Classical Assumptions

a. Normality test

b. Multicollinearity Test

c. Heteroscedasticity Test

d. Autocorrelation Test

4. Multiple Linear Regression

Multiple linear regression analysis is used to determine the effect of independent or independent variables on dependent or dependent variables. The formula is as follows :

$\mathrm{Y}=\mathrm{a}+\mathrm{b}_{1} \mathrm{X} 1+\mathrm{b} 2 \mathrm{X} 2$ $+\mathrm{b} 1 \mathrm{X} 3+\mathrm{e}$

5. Correlation Coefficient Test

6. Coefficient of Determination

7. $\mathrm{T}$ test

8. F Test

3.5. Research and measurement variables

1. Dependent variable (Y) is the satisfaction of AIS users.

The research instrument for independent variables was satisfaction using questionnaires with 10 questions, while measurements using the Likert scale 1 to 5 from the level strongly agree to strongly disagree.

2. Independent variable (X1), namely the skills of AIS users

The research instrument for independent variables is satisfaction using the questionnaire itself with 4 questions, while the measurement using the Likert scale 1 to 5 from the level of strongly agree to strongly disagree.

3. Independent variable (X2), namely the ability of AIS users

The research instrument for independent variables was the ability to use the Puti aryani questionnaire (2014) with 4 questions, while the measurement using a Likert scale of 1 to 5 from the level strongly agreed to strongly disagree

4. Independent variable (X3), namely education and training of AIS users

The research instruments for independent variables were education and training using the Putri Aryani questionnaire (2014 with 5 questions, while measurements using the Likert scale 1 to 5 from the level strongly agreed to strongly disagree.

\section{RESULTS AND DISCUSSION}

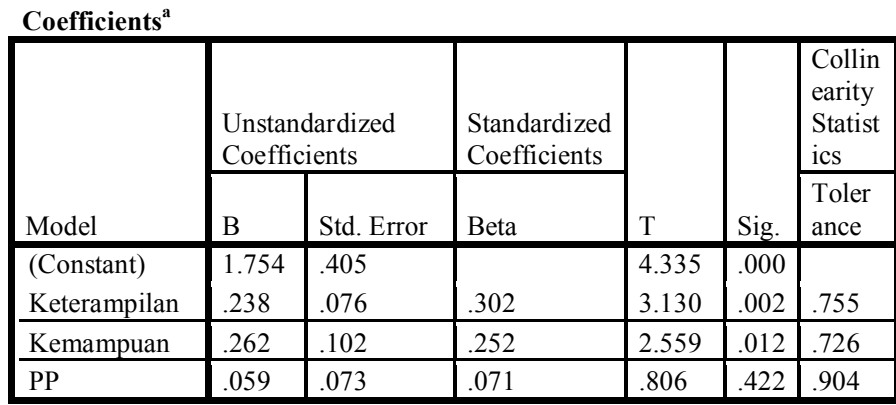

1. Effect of the skills of AIS users on the satisfaction of AIS users

The table above is done to test the Hypothesis 1 Test: The effect of AIS user skills on the satisfaction of AIS users. From the results of the above calculations, it can be seen that the significance value $<0.05$ is $0.002<0.05$, this means that $\mathrm{H} 1$ is accepted, so there is a significant influence between the skills of AIS users and the satisfaction of AIS users. Thus the increasing skills of AIS users in the company will increase the satisfaction of AIS users in the company.

This study supports the research conducted by Mahdiar Rahmi (2008) with influential and significant results, and this study is also in line with research conducted with Laudon's theory (2008), users need to know and 
understand the information technology used by companies in information system. If the user has the expertise and understanding of the system used, the user will feel more have the system used, so they can use the system properly. Also in line with Rini's research (2009), the results show that user expertise has a significant positive effect on the implementation of AIS.

2. Effect of AIS User Ability on AIS User Satisfaction

The table above is done to test the Hypothesis Test 2: Effect of the ability of AIS users on AIS user satisfaction. From the above calculation results it can be seen that the significance value is $<0.05$, which is $0.012<0.05$. This means that $\mathrm{H} 2$ is accepted, so there is a significant effect AIS users with AIS user satisfaction. Thus the increasing ability of AIS users in the company will increase the satisfaction of AIS users in the company.

The results of this study are in line with Cecilia and Ellen (2010), Soegiharto (2001) but are not in line with the research conducted by Choe (1996), Sasmita (2003), Almilia and Brilintien (2007) which state the ability of information system users to have a positive effect and not significant.

3. Effect of AIS User Education and Training on AIS User Satisfaction.

The table above is done to test the Hypothesis 3 Test: Effect of AIS education and training on AIS user satisfaction. From the results of the above calculations, it can be seen that

\section{REFERENCES}

$$
\begin{aligned}
& \text { Adiputra I made , } 2011, \text { Pengaruh } \\
& \text { partisipasi pemakai } \\
& \text { kepuasaan perhadap } \\
& \text { pengembangan sistem informasi } \\
& \text { akuntansi dengan tiga variabel }
\end{aligned}
$$

the significance value $>0.05$ is $0.422>$ 0.05 , which means that $\mathrm{H} 3$ is rejected. insignificant between Education and training of AIS users with satisfaction of AIS users. Thus the increasing education and training of AIS users in the company will have no significant effect on the satisfaction of AIS users in the company.

This study is not in line with the research of cicilia and elen (2010) Almilia and Briliantien (2007) where education and training have a significant effect on user satisfaction, and according to the results of the study by Soegiharto (2001).

\section{CONCLUSION}

5.1. Conclusion

The conclusion obtained from this study is

1. The skills of AIS users affect the satisfaction of AIS users.

2. The ability of AIS users affect the satisfaction of AIS users

3. Education and training of AIS users affect the satisfaction of AIS users.

\subsection{Suggestion}

The researcher can add other variables which are signaled to have an effect on the satisfaction of AIS users.

moderasi pada pasar swalayan di kota Denpasar.

Al-Ghatani, Said S. 2001. "The Applicabilitycof TAM Outside North America: An Empirical Test in the United Kingdom. 
Almilia, L. S., dan I. Briliantien. 2007. Faktor-faktor yang mempengaruhi kinerja sistem informasi akuntansi pada bank umum pemerintah di wilayah surabaya dan sidoarjo. Jurnal STIE Perbanas Surabaya

Agung, Anak dan Putra, I Nyoman. 2005."Pemanfaatan TI dan Pengaruhnya pada Kinerja Individual pada Bank Perkreditan Rakyat di Kabupaten Tabanan".Jurnal Akuntansi. Vol 5 no 1 hal 1

Bondan Dwi , 2012 , Pengaruh Kepuasaan pengguna sistem informasi terhadap kinerja individu .

Bodnar 2004. Sistem Informasi Akuntansi, (Terjemahan AmirAbadi Jusuf dan Tambunan). Buku Satu. Jakarta : Salemba Empat

Davis. 1989. Perceived Usefullness, Perceived ease of use of Information Technology. Management Information System Quarterly, 21 (3), 319-340.

Cecilia dan Ellen, 2010 , Kinerja Sistem Informasi Akuntansi ( AIS ) di tinjau dari kepuasaan pemakai AIS yang dipengaruhi oleh partisipasi , kemampuan , pelatihan dan pendidikan pemakai AIS.

Choe, J.M., 1996, The Relationships Among Performance of Accounting Information Systems, Influence Factors, and Evolution Level of Information Systems, Journal of Manahement Information System, Vol.12, No.4, Spring: 215-239

Ghozali, Imam. 2011. Aplikasi Ananlisis Multivariate Dengan Program SPSS. Semarang: Badan Penerbit Universitas Diponogoro.

Guimaraes, T., D. S. Staples, dan J. D. McKeen. 2007. Assessing the
Impact From Information System Quality, Quality Management Journal, 14(1): 30- 44.

Istianingsih dan Setyo 2008 , Pengaruh kualitas sistem informasi , perceived usefulness dan kualitas informasi terhadap kepuasaan pengguna akhir software akuntansi

Iskandar. 2008. Metodologi Penelitian Pendidikan dan SoAIS1 (Kuantitatif dan Kualitatif). Jakarta: Gaung Persada Pres.

Kritiani wahyu , 2012 , Analisis pengaruh efektivitas teknologu sistem informasi akuantansi terhadap kinerja individul pegawai PT. Kim Eng Sekuritas IndoneAIS.

Laudon, Kenneth C, dan Jane P. L. 2008. Sistem Informasi Manajemen; Mengelola Perusaan Digital. Edisi 10. Jakarta: Salemba Empat

Rahmi Mahdiar , 2008 , Pengaruh Pengguna Teknologi infomasi dan keahlian pemakai terhadap kualitas informasi akuntansi.

Romney, B. M. Dan P. J. Steinbart. 2006. Sistem Informasi Akuntansi. Jakarta: Edisi 9. Salemba Empat.

Rini Susanti. 2009. Pengaruh Penggunaan Teknologi Informasi dan Keahlian Pemakai terhadap Penerapan Sistem Informasi Akuntansi. Skripsi FE UNP

Sugiyono. 2012. Metode Penelitian Kuantitatif Kualitatif dan R\&D. Alfabeta. Bandung.

Soegiharto, 2001, Influence Factors Affecting The Performance of Accounting Information Sistems, Gajah Mada International Journal of Business, Vol.3, No.2, Mei: 177-202 